Omni-Akuatika, 14 (1): 108-117, 2018
ISSN: 1858-3873 print / 2476-9347 online
Research Article
iournal homepaqe: http://ois.omniaquatika.net

\title{
Soft Coral (Sinularia sp.) Extracts with Antibacterial Activity
}

\author{
Wendy Alexander Tanod ${ }^{1,2^{\star}}$, Anita Treisya Aristawati ${ }^{1}$, Masteria Yunovilsa Putra ${ }^{3}$, and Muliadin ${ }^{1}$ \\ ${ }^{1}$ Institute of Fisheries and Marine Palu (Sekolah Tinggi Perikanan dan Kelautan - STPL Palu), Indonesia \\ ${ }^{2}$ Doctoral Program, Fisheries and Marine Science Faculty, Brawijaya University, Malang, Indonesia \\ ${ }^{3}$ Research Center for Oceanography, Indonesian Institute of Sciences, Indonesia \\ *Corresponding author: wendytanod@stplpalu.ac.id
}

Received December 2018; Accepted 28 Mei 2018; Available online 31 May 2018

\begin{abstract}
There is a growing need for new antibacterial agents, in particular because many antibiotics are becoming ineffective due to the emergence of resistant bacterial strains. Soft corals of the Genus Sinularia, Family Alcyoniidae, have potential as a source of terpenoid and steroid compounds with antibacterial activity. These corals may vary in external morphology (shape, colour, size). The aim of this research was to identify extracted fractions with high antibacterial activity. Sinularia sp. specimens were extracted, fractionated based on solvent polarity, and tested for antibacterial bioactivity against pathogenic bacteria (Escherichia coli and Staphylococcus aureus). Antibacterial activity of the three fractions varied in strength. The dichloromethane fraction showed strong antibacterial activity, inhibiting $S$. aureus and $E$. coli growth at a concentration of $1 \mathrm{mg} \mathrm{ml}^{-1}$, while the ethyl acetate and ethanol fractions were effective at $10 \mathrm{mg} \mathrm{ml}^{-1}$ and $100 \mathrm{mg} \mathrm{ml}^{-1}$, respectively.
\end{abstract}

Keywords: Antibacterial compounds, Soft Coral, Sinularia sp., Escherichia coli, Staphylococcus aureus

\section{Introduction}

Physiologically marine organisms have the potential to develop unique metabolites, to survive in extreme marine environments, including secondary metabolites with beneficial chemical and biological properties which are not produced by terrestrial organisms (Blunt et al., 2009). Soft corals can contain a variety of biologically active secondary metabolites (e.g. sesquiterpenes, diterpenes and steroids), with anti-inflammatory (Cheng et al., 2010), antimitotic (Tanod et al., 2015), cytotoxic (Zhao et al., 2013), antiviral (Wang et al., 2013) and antibacterial (Ishii et al., 2009; Bishara et al., 2007) properties.

The oceans of eastern Indonesia contain a high biodiversity of marine organisms (Tapilatu, 2015). Thus, these oceans could be central to the discovery of new medicinal compounds from marine organisms (Leal et al., 2012). Exploratory research for bioactive compounds has been carried out on sponges and algae from Indonesian oceans (Sukoso et al., 2012; Aoki et al., 2004 and Hassan et al., 2004). However, there has been a lack of research on bioactive compounds from soft corals, in particular with respect to antibacterial potency.

Soft coral is a term commonly used for the members of the Alcyoniidae Family. With their varying shapes, colours, sizes and types, these soft corals are often the dominant coral reef organisms in the western Indo-Pacific oceans (Putra et al., 2016). It has been suggested that the soft coral genus Sinularia could be a source of terpenoids and steroid derivative compounds (Lu et al., 2008). Some recent research (20122016) showed that Sinularia sp. could have antibacterial activity potential (Putra et al., 2016; Afifi, Abdel-Nabi, \& El-Shaikh, 2016; Rajaram et al., 2014; Rozirwan et al., 2014; Liang et al., 2013; Sun et al., 2012).

An antibacterial compound is a substance that can inhibit growth or kill bacteria (Gan, Udin, \& Vincent, 1980). The World Health Organization stated that the world requires active substances with broad spectrum antibacterial activity to 
address the problem of increasing antibiotic resistance (Radić \& Strukelj, 2012). Bacterial pathogens Enterococcus faecium, Staphylococcus aureus, Klebsiella pneumoniae, Acinetobacter baumanii, Pseudomonas aeruginosa, and Enterobacter sp. are the cause of infectious diseases in humans, and several studies have shown that many antibacterial drugs are (now) ineffective against this group of bacteria (Rice, 2008).

Wright \& Sutherland (2007) suggest that the need for new compounds with antibacterial activity will continue to rise because some existing antibiotics are no longer effective against infections that threaten human life. Therefore, the search for new antibacterial compounds should continue. The purpose of this study was to obtain compounds (extracted and fractionated) from soft corals (Sinularia sp.) and test them for antibacterial bioactivity against pathogenic bacteria Escherichia coli and Staphylococcus aureus.

\section{Materials and Methods}

\subsection{Location and time}

The research was conducted between May and September 2017. Extraction and assay of antibacterial activity were conducted at the Fisheries Product Technology Laboratory of Palu Fisheries and Marine Institute and Agrotechnology Laboratory of Tadulako University.

\subsection{Materials and equipment}

Materials used included: soft corals Sinularia sp., nutrient agar (Merck), nutrient broth (Merck), bacteriological agar (Hi-Media), distilled water, $70 \%$ alcohol, dichloromethane (Merck), ethyl acetate (Merck), ethanol (Merck), DMSO (Merck), tissue, cotton, gauze, Whatman filter paper, aluminium foil, plastic wrap, plastic samples, chloramphenicol and ampicillin (generic), bacterial isolates Escherichia coli and Staphylococcus aureus (from the Microbiology Laboratory, Faculty of Medicine, Brawijaya University, Malang). The equipment used, included: laminar air flow cupboard, autoclave, analytical scales, Petri dishes, test tubes, Erlenmeyer glasses, incubator, oven, glass jars, ose needles, tweezers, Bunsen burner, masks, gloves, micro pipettes, droppers, rotary vacuum evaporator, McFarland Standard (Hi-Media), and well mould.

\subsection{Soft coral sampling and extraction}

Soft coral Sinularia sp. samples were obtained from a stock in the Fisheries Technology Production Laboratory of the Palu Fisheries and Marine College, which was collected by hand using SCUBA and preserved through freezing. The samples were collected at 3-5 $\mathrm{m}$ depth, off the coast of Kabonga Besar, Donggala District, Palu Bay at coordinates 43.31 LS and 119.46 BT in December 2016. Identification of soft corals by Masteria Yunovilsa Putra, PhD. The (defrosted) soft coral samples were cut into cubes (approximately $1 \mathrm{~cm}^{3}$ ), inserted into glass jars (approximately $500 \mathrm{~g} / \mathrm{jar}$ ), then macerated with $1: 2 \mathrm{w} / \mathrm{v}$ dichloromethane (DCM) for 48 hours, and then filtered. The maceration and filtration process was repeated three times. The filtrate obtained was evaporated using an organic solvent. The crude extract was weighed. The remaining soft coral debris was further macerated in stages, firstly with ethyl acetate (EtOAc) and then with ethanol (EtOH). A flowchart of the extraction process can be seen in Figure 1.

\subsection{Antibacterial activity assay}

The agar diffusion antibacterial activity assay technique was used. This method uses two layers of agar: a base layer and a seeding layer. The base layer is made by dissolving $2 \mathrm{~g}$ nutrients and $2 \mathrm{~g}$ bacteriological agar in $100 \mathrm{ml}$ distilled water; the mixture is heated until homogenized and sterilized in an autoclave for 15 minutes at $121{ }^{\circ} \mathrm{C} ; \pm 15 \mathrm{ml}$ are then poured into a sterile Petri dish and left to solidify. The seeding layer is made from $1.4 \mathrm{~g}$ nutrient agar dissolved in $100 \mathrm{ml}$ distilled water, heated while stirring until homogenized; the mixture is poured into test tubes (9 $\mathrm{ml}$ each), and sterilized in an autoclave at a temperature of $121{ }^{\circ} \mathrm{C}$ for 15 minutes. Test bacteria $\left(1 \mathrm{ml}\right.$, density $\left.10^{6} \mathrm{CFU} / \mathrm{ml}\right)$ were added to each tube. The contents were compared to standard McFarland solution (HiMedia) No. 4 (Density $1.2 \times 10^{9} \mathrm{CFU} / \mathrm{ml}$ ), then vortexed, poured over the base layer, and the well mould inserted. The media was left until solid, before adding $50 \mu \mathrm{l}$ drops of extract to each test well, with a concentration of 1000,100 , 10 or $1 \mathrm{mg} \mathrm{ml}^{-1}$. The test extract was compared with positive controls (ampicillin and chloramphenicol) with concentrations of $1,0.1$ and $0.01 \mathrm{mg} \mathrm{ml}^{-1}$ (Rina, 2011). The inoculated media was incubated at $37^{\circ} \mathrm{C}$ for 24 hours, after 
which the clear zone formed around each well was observed and measured. Antibacterial activity was evaluated using the categories in Latifah (2008), based on clear zone diameter: a diameter of $20 \mathrm{~mm}$ or more means antibacterial activity is very strong, $10-20 \mathrm{~mm}$ is considered strong, $5-10 \mathrm{~mm}$ is medium and $5 \mathrm{~mm}$ or less is weak.

\subsection{Determination of Minimum Inhibitory Concentration (MIC) and Minimum Bactericidal Concentration (MBC)}

MIC is the minimum concentration of extract that can inhibit the growth of test bacteria while $\mathrm{MBC}$ is the minimum concentration of extract that can kill bacteria. Determination of
MIC and MBC values followed the methods of Bloomfield, (1991), graphing the linear regression of $\ln \mathrm{Mo}=\ln \mathrm{Mt}$ on the $\mathrm{X}$ axis against $\mathrm{Z}^{2}$ (quadratic value of resistor zone diameter) on the $Y$ axis. The $M t$ is the $X$ axis intercept of the linear regression line. The $\mathrm{MIC}=0.25 \mathrm{Mt}$ and the $\mathrm{MBC}=4 \times \mathrm{MIC}$.

\subsection{Zoochemical assay}

Each soft coral extract fraction was subjected to an initial zoochemical screening assay to determine the presence of secondary metabolites (alkaloids, flavonoids, steroids, triterpenoids, saponins and polyphenols) using conventional standard protocols as described by Harborne, (1998).

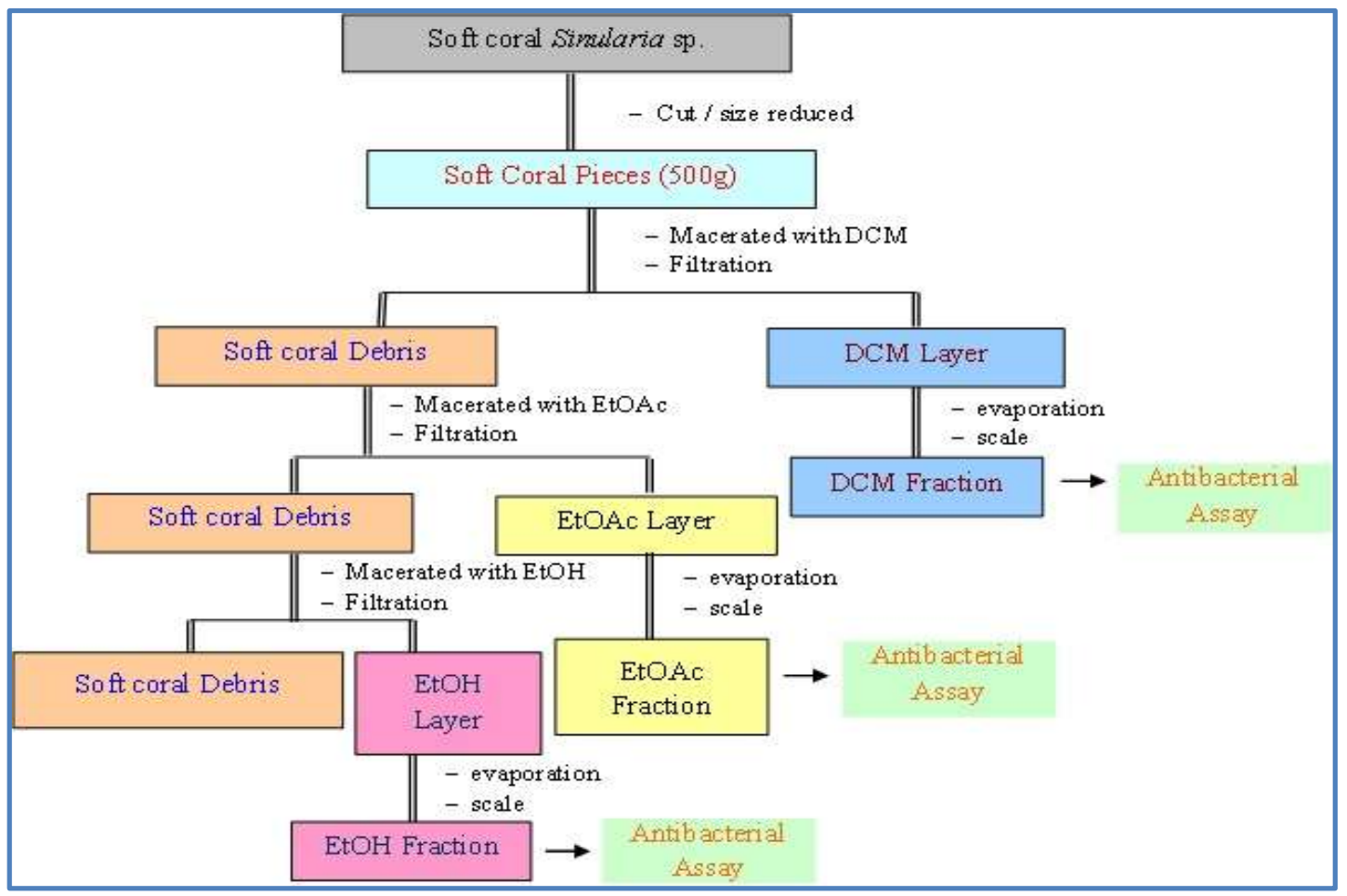

Figure 1. Soft Coral Sinularia sp. Compound Extraction and Fractionation Flowchart 


\section{Results and Discussion}

Based on the form of monomorphic colony, soft corals used in this research were identified as Sinularia sp. as shown in Figure 2 below. The results on the zoochemical assays used to determine the bioactive components contained in the three soft coral Sinularia sp. extract fractions used in this research can be seen in Table 1 and Figure 3. Based on this identification, soft coral Sinularia sp. extracts contained compounds belonging to the saponins, steroids, alkaloids and polyphenols. Saponin is characterized by a bitter taste and is toxic to some fish and amphibians, and have pharmaceutical applications (Rachmaniar, 1995). The usefulness of saponins for soft corals include roles in deterring predatory attacks, as a weapon in competing for space, and in assisting the process of reproduction (L. F. Liang \& Guo, 2013).

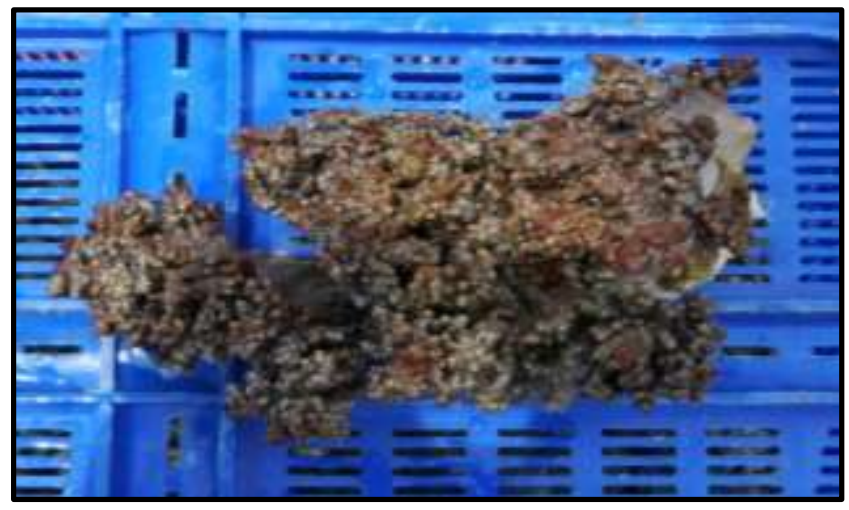

Figure 2. Soft Coral Sinularia sp

Table 1. Soft Coral Sinularia sp. Extract Zoochemical Test results

\begin{tabular}{lcccl}
\hline \multirow{2}{*}{ Zoochemical } & \multicolumn{3}{c}{ Fraction } & \multicolumn{2}{c}{ Standard } \\
\cline { 2 - 4 } & DCM & EtOAc & EtOH & \\
\hline Saponin & + & - & - & Stable foam formed for 15 minutes \\
Polyphenol & - & + & + & Brown precipitate formed \\
Steroid & + & + & - & Green or blue colour produced \\
triterpenoid & - & - & - & Brown or reddish-brown colour produced \\
Alkaloid & + & + & - & Orange precipitate formed \\
Flavonoid & - & - & - & Orange, pink or red colour produced \\
\hline
\end{tabular}

Soft corals Sinularia sp. contain diterpene and steroid compounds that have showed anticancer, anti-inflammatory, anti-allergic and antibacterial activity (Jia et al., 2005). Handayani et al. (1997) suggests the steroid compounds in the soft coral body play a role in protection against predators that threaten their survival. Putra et al., (2016) also reported the presence of steroid and saponin compounds in soft corals of
Sinularia sp., while Rajaram et al., (2014) isolated two steroid compounds from soft corals Sinularia kavarattiensis, and Liang et al., (2013) isolated steroid compounds from Sinularia depressa Tixier-Durivault, and new steroid compounds have been isolated from Sinularia polydactyla (Shaaban, Shaaban, \& Ghani, 2013). 


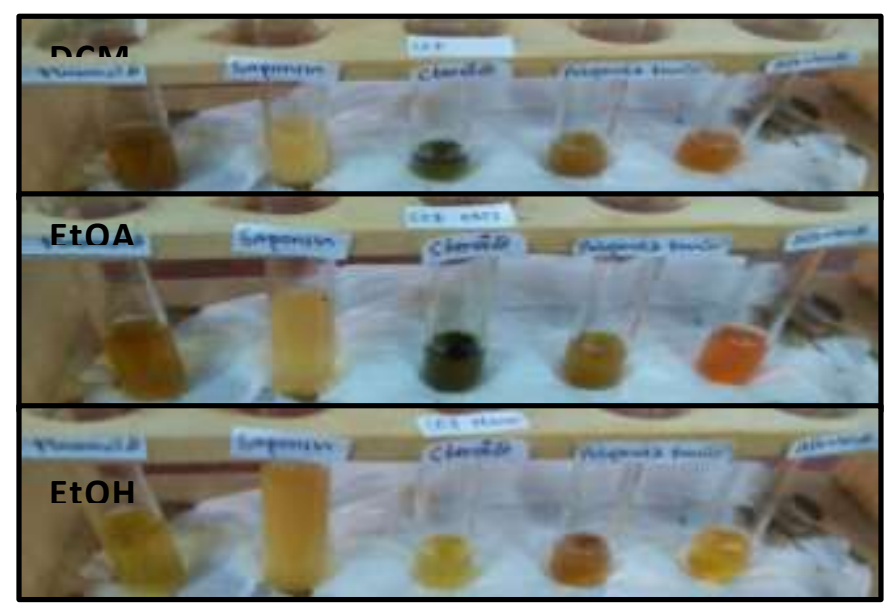

Figure 3. Zoochemical Assay Result of Sinularia sp. Extract

The three fractions of the Sinularia sp. soft coral were assayed for potential antibacterial activity against Staphylococcus aureus (gram positive) and Escherichia coli (gram negative) bacteria at concentrations of $1,000,100,10$ and $1 \mathrm{mg} \mathrm{ml}^{-1}$. The results of the antibacterial activity assay are presented in Table 2, and show activity in the Strong, Medium and Weak categories (Latifah, 2008). The dichloromethane fraction showed strong antibacterial activity, still inhibiting the growth of $S$. aureus and $E$. coli bacteria at the $1 \mathrm{mg} \mathrm{ml}^{-1}$ concentration. The ethyl acetate fraction inhibited bacterial growth down to $10 \mathrm{mg} \mathrm{ml}^{-1}$, while the ethanol fraction was only effective down to $100 \mathrm{mg} \mathrm{ml}^{-1}$.

Table 2. Sinularia sp. Extract Antibacterial Assay Results

\begin{tabular}{|c|c|c|c|}
\hline \multirow{2}{*}{ Fraction } & \multirow{2}{*}{$\begin{array}{c}\text { Concentration } \\
\mathrm{mg} \mathrm{ml}^{-1}\end{array}$} & \multicolumn{2}{|c|}{ Clear Zone Diameter (mm) } \\
\hline & & E. coli & S. aureus \\
\hline \multirow{4}{*}{$\begin{array}{l}\text { Dichloromethane } \\
\text { (DCM) }\end{array}$} & 1.000 & $13,10 \pm 1,45$ & $14,73 \pm 0,75$ \\
\hline & 100 & $8,43 \pm 1,15$ & $9,43 \pm 0,75$ \\
\hline & 10 & $5,67 \pm 0,65$ & $5,20 \pm 1,15$ \\
\hline & 1 & $0,53 \pm 0,12$ & $0,53 \pm 0,12$ \\
\hline \multirow{4}{*}{$\begin{array}{l}\text { Ethyl Acetate } \\
\text { (EtOAc) }\end{array}$} & 1.000 & $15,20 \pm 1,01$ & $14,40 \pm 0,85$ \\
\hline & 100 & $7,40 \pm 1,01$ & $7,00 \pm 0,30$ \\
\hline & 10 & $3,97 \pm 0,35$ & $3,73 \pm 0,67$ \\
\hline & 1 & 0 & 0 \\
\hline \multirow{4}{*}{$\begin{array}{l}\text { Ethanol } \\
\text { (EtOH) }\end{array}$} & 1.000 & $17,63 \pm 1,74$ & $17,43 \pm 2,29$ \\
\hline & 100 & $5,47 \pm 0,23$ & 0 \\
\hline & 10 & 0 & 0 \\
\hline & 1 & 0 & 0 \\
\hline \multirow{3}{*}{ Ampicillin } & 1 & $14,74 \pm 1,20$ & $7,63 \pm 1,48$ \\
\hline & 0,1 & $7,6 \pm 2,83$ & $3,30 \pm 1,65$ \\
\hline & 0,01 & 0 & 0 \\
\hline \multirow{3}{*}{ chloramphenicol } & 1 & $19,30 \pm 5,37$ & $15,30 \pm 0,92$ \\
\hline & 0,1 & $15,43 \pm 4,03$ & $6,40 \pm 2,55$ \\
\hline & 0,01 & 0 & 0 \\
\hline
\end{tabular}


Rozirwan et al., (2014) reported antibacterial activity against $E$. coli and $S$. aureus from the semi-polar (EtOAc) and polar $(\mathrm{MeOH})$ fractions on soft corals Sinularia sp., Sinularia polydactyla and Sinularia flexibilis. Rozirwan et al., (2014) also suggests that Sinularia has a strong inhibitory effect on pathogenic bacterial growth. Soft coral Sinularia sp. also showed moderate to strong antibacterial potential against gram-positive bacteria ( $B$. subtilis and $S$. aureus) and gram-negative bacteria (E. coli and V. eltor) (Putra et al., 2016).

The data in Table 2 show that soft coral extracts from the DCM fraction inhibited the growth of $S$. aureus more effectively than $E$. coli. For the EtOAc Fraction, the clear zone formed was greater for $E$. coli than $S$. aureus, while the $\mathrm{EtOH}$ fraction can inhibit $E$. coli more strongly than $S$. aureus, because at $100 \mathrm{mg} \mathrm{ml}^{-1}$ concentration there was still an inhibition zone for E. coli.

The MIC analysis results showed that the minimum inhibitory concentrations of DCM, EtOAc and $\mathrm{EtOH}$ fractions against $E$. coli bacteria were $6.63 ; 3.38 ; 60.2 \mathrm{mg} \mathrm{ml}^{-1}$, respectively; against $S$. aureus bacteria, the minimum inhibitory concentrations were 7.21 ; 2.91; $127.97 \mathrm{mg} \mathrm{ml}^{-1}$, respectively. The MBC analysis results for DCM, EtOAc and EtOH fractions of soft coral Sinularia sp. against E. coli bacteria were 26.53; $13.51 ; 240.73 \mathrm{mg} \mathrm{ml}^{-1}$, respectively; against $S$. aureus bacteria, they were $28.84 ; 11.65 ; 511.87 \mathrm{mg} \mathrm{ml}^{-1}$, respectively. The results of assays against $E$. coli bacteria can be seen in Figure 4.

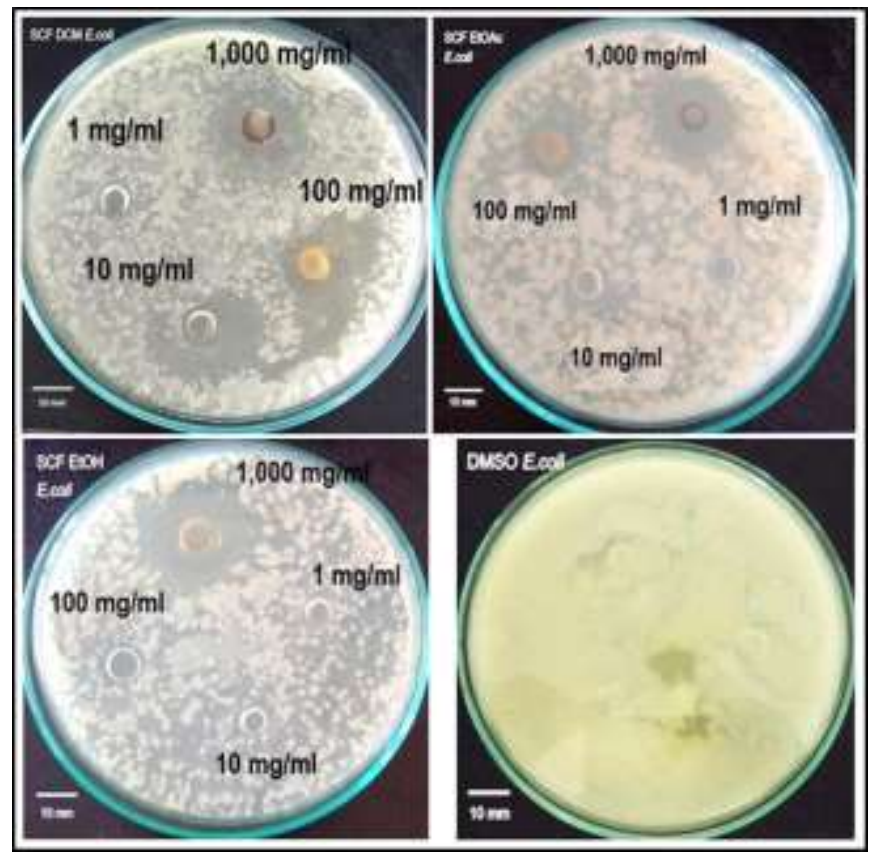

Figure 4. Results of Soft Coral Sinularia sp. Extract Assays Against E. coli

Gram negative bacteria such as $E$. coli have an additional layer in the cell wall structure, known as the outer membrane. This membrane is composed of lipopolysaccharides (LPS), a porin matrix, and lipoproteins. The presence of a special membrane of protein molecules (porin) in gram-negative bacteria can facilitate the passive diffusion of low molecular weight hydrophilic compounds. Molecules that are hydrophilic find it easier to pass through LPS than those which are hydrophobic (Jawetz,
Melnick, \& Adelberg, 2008). Gram-negative bacteria have a hydrophilic end, i.e. carboxyl, amino acids, and hydroxyl so that gram-negative bacteria are sensitive to polar antibacterial compounds (Madigan, Martinko, \& Parker, 2000). Therefore, the ethanol fraction still showed a noticeable inhibition zone against $E$. coli at concentrations of $100 \mathrm{mg} \mathrm{ml}^{-1}$ but not against $S$. aureus.

The resistance of gram negative and gram positive bacteria to antibacterial 
compounds is different. Gram-negative bacteria are generally sensitive to polar antimicrobial compounds, whereas gram-positive grains are more sensitive to non-polar antibacterial compounds (Brannen \& Davidson, 1993). The differences in sensitivity of gram-positive and gram-negative bacteria are related to the structure within the cell wall, such as the number of peptidoglycans (the presence of receptors, pores, and lipids), the nature of the cross-linking, and the activity of the autolithic enzymes. These components are factors that determine the penetration, binding, and activity of antimicrobial compounds (Jawetz et al., 2008). Assay results of $S$. aureus bacteria can be seen in Figure 5 .

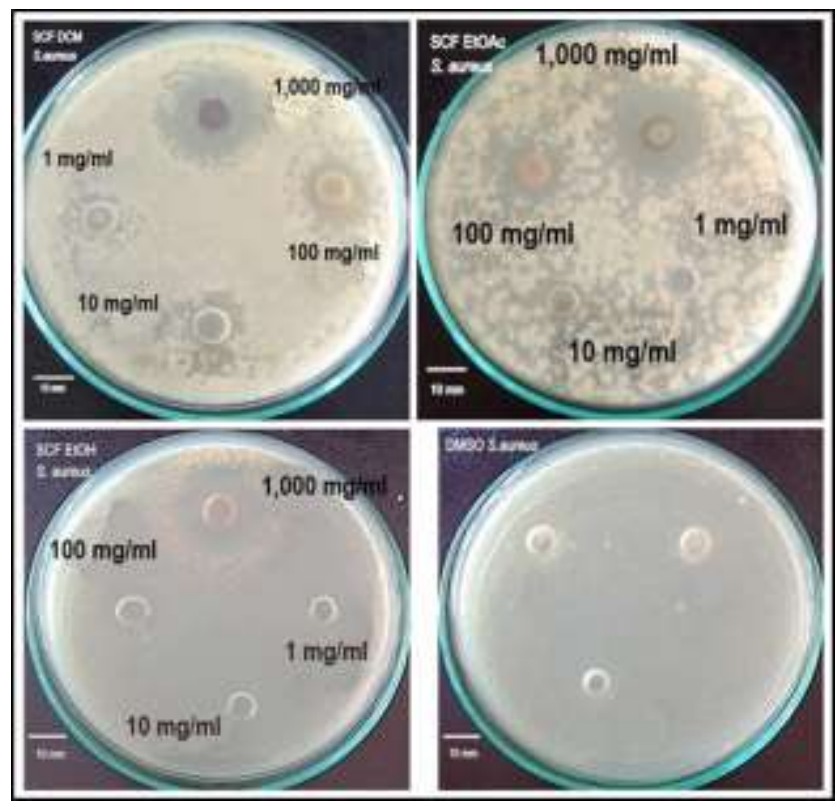

Figure 5. Results of Soft Coral Sinularia sp. Extract Assays Against S. aureus

The soft coral of the genus Sinularia are a rich source of polyhydroxygenated steroids (Lakshmi \& Kumar, 2009 and Sarma et al., 2009). The steroid derivatives $(3 \beta, 5 \alpha, 6 \beta)$-ergost-24(28)-en-3,5,6,19 tetrol 19-monoacetate isolated from the soft coral Sinularia depressa Tixier-Durivault also showed considerable antibacterial activity against $S$. aureus (Liang et al., 2013). Rajaram et al., (2014) also reported

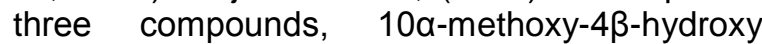
guaine-6-ene; $1 \mathrm{~S}^{*}, 4 \mathrm{~S}^{*}, 5 \mathrm{~S}^{*}, 10 \mathrm{R}^{*}-4,10$ guaianediol and one new sesquiterpene compound exhibiting moderate to strong antibacterial activity against $B$. subtilis, $S$. aureus, S. epidermidis, E. coli, $P$. aeruginosa and $K$. pneumoniae. However, the results of Shaaban et al., (2013), evaluating the antibacterial activity of 5 terpenes and steroids from Sinularia polydactyla against $B$. subtilis, $S$. aureus, Streptomyces viridochromogenes (Tü $57)$ and E. coli did not show antibacterial activity potential. On the other hand, Afifi et al., (2016)showed that soft corals Sinularia polydactyla have good antibacterial activity against positive gram bacterium Bacillus spp. and $S$. aureus, and no inhibitory activity in negative gram bacterium $E$. coli .Sun et al., (2012) showed that two compounds, sinularosides A and B from Sinularia humilis Ofwegen had antibacterial potential against gram-positive Bacillus megaterium while there was no inhibition of $E$. coli. The differences in observed antibacterial activity even within the same soft coral species indicate that environmental factors might affect the bioactive compounds present in an organism (Harborne, 1998).

As an antibacterial control, the chloramphenicol inhibition zone diameters for the test bacteria were greater than those around the soft coral extracts. This is likely due to the characteristics of chloramphenicol which is a highly stable antibacterial compound and diffuses well in seeding agar (Rahal \& Simberkoff, 1979). Ampicillin is a semi-synthetic drug belonging to the Penicillin class of antibiotics, and has been shown to be effective against a wide range of infections caused by 
Gram-positive bacteria and some Gramnegative. Ampicillin acts by inhibiting the synthesis of bacterial cell walls, eventually resulting in cell lysis (Ashnagar \& Naseri, 2007). The result of positive control antibacterial tests can be seen in Figure 6.

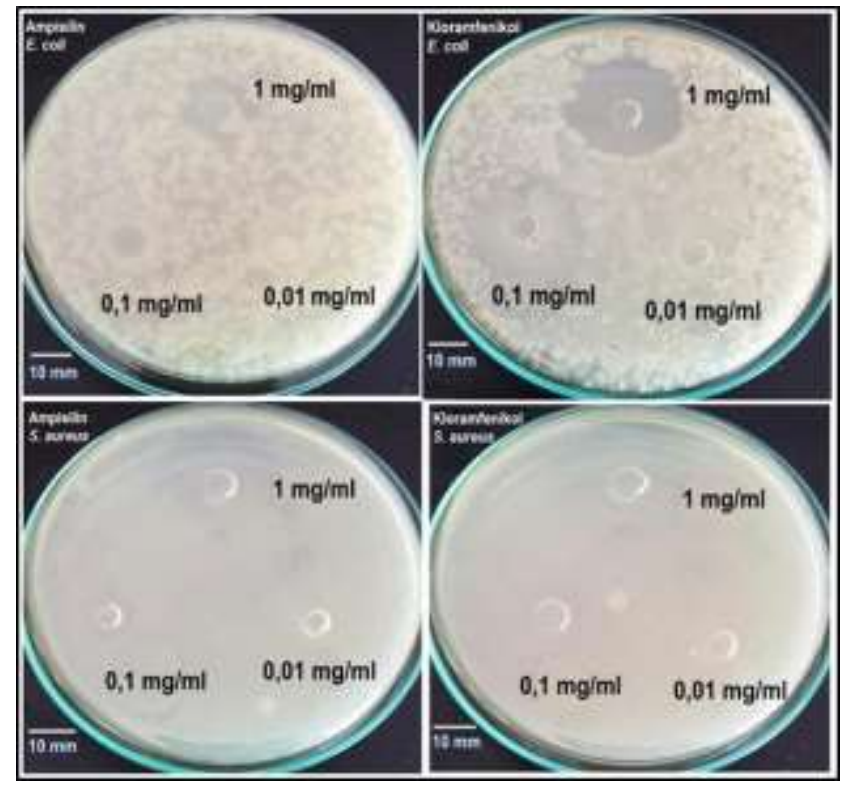

Figure 6. Positive Control Antibacterial Assays; Ampicillin (left) and chloramphenicol (right) against E. coli (above) and S. aureus (below)

\section{Conclusion}

A series of antibacterial assays showed that the soft corals of the Genus Sinularia tested contained compounds which exhibit antibacterial activity, some of which may have potential as new or alternative antibacterial agents. The dichloromethane fraction showed the strongest antibacterial activity. Further research is recommended, in particular purification and characterization of the dichloromethane fraction, to identify the compounds responsible for this antibacterial activity.

\section{Acknowledgments}

The Authors wish to thank the Directorate General for Research and Development, Ministry of Technology, Research, and Higher Education for support under the 2017 junior lecturer research grant scheme. Thanks also go to the Director of the Palu Fisheries and Marine Institute who provided facilities and support to enable the completion of this research.

\section{References}

Afifi, R., Abdel-Nabi, I. M., El-Shaikh, K. 2016. Antibacterial activity from soft corals of the
Red Sea, Saudi Arabia. Journal of Taibah University for Science, 10(6), 887-895.

Ashnagar, A., Naseri, N. G. 2007. Analysis of Three Penicillin Antibiotics (Ampicillin, Amoxicillin and Cloxacillin) of Several Iranian Pharmaceutical Companies by HPLC. E-Journal of Chemistry, 4(4), 536545.

Bishara, A., Rudi, A., Benayahu, Y., Kashman, Y. 2007. Three biscembranoids and their monomeric counterpart cembranoid, a biogenetic diels-alder precursor, from the soft coral Sarcophyton elegans. Journal of Natural Products, 70(12), 1951-1954.

Bloomfield, S. F. 1991. Methods For Assesing Antimicrobial Activity In Mechanism of Action of Chemical Biocides Thesis Study and Explanation. (S. . Denyer \& B. W. Hogo, Eds.). London: Blackwell Scientific Publication.

Blunt, J. W., Copp, B. R., Hu, W.-P., Munro, M. H. G., Northcote, P. T., Prinsep, M. R. 2009. Marine natural products. Natural Product Reports, 26(2), 170-244.

Brannen, A.., Davidson, P. (1993). Antimicrobial 
in Foods. New York: Marcel Dekker.

Cheng, S.-Y., Huang, K.-J., Wang, S.-K., Wen, Z.-H., Chen, P.-W., Duh, C.-Y. 2010. Antiviral and anti-inflammatory metabolites from the soft coral Sinularia capillosa. Journal of Natural Products, 73(4), 771-775.

Gan, S. ., Udin, A., Vincent, H. S. . 1980. Farmakologi Dan Terapi (Edisi Kedua). Jakarta: Fakultas Kedokteran Universitas Indonesia.

Handayani, D., Edrada, R. A., Proksch, P., Wray, V., Witte, L., Van Ofwegen, L., Kunzmann, a. 1997. New oxygenated sesquiterpenes from the Indonesian soft coral Nephthea chabrolii. Journal of Natural Products, 60(7), 716-718.

Harborne, J. B. 1998. Phytochemical Methods; A Guide to Modern Techniques of Plant Analysis. Journal of Chemical Information and Modeling (Vol. 3). London New York: Chapman and Hall.

Ishii, T., Matsuura, H., Zhan, Z. Q., Vairappan, C. S. 2009. A New Norsesquiterpenoid from a Bornean Soft Coral Genus Nephthea. Molecules, 14(11), 4591-4596.

Jawetz, Melnick., Adelberg. 2008. Mikrobiologi Kedokteran. PhD (Edisi Ke-2). Jakarta: EGC.

Jia, R., Guo, Y., Mollo, E., Cimino, G. 2005. Natural Product Research: Formerly Natural Product Letters Two new 19oxygenated polyhydroxy steroids from the hainan soft coral Sinularia sp . Natural Product Research, 19(8 December 2005), 789-794.

Lakshmi, V., Kumar, R. 2009. Metabolites from Sinularia species. Natural Product Research, 23(9), 801-850.

Latifah, Q. A. 2008. Uji Efektifitas Ekstrak Kasar Senyawa Antibakteri Pada Buah Belimbing Wuluh (Averrhoa bilimbi L.) Dengan Variasi Pelarut. Skripsi. Universitas Islam Negeri (UIN) Malang.

Liang, L.-F., Wang, X.-J., Zhang, H.-Y., Liu, H.L., Li, J., Lan, L.-F., Guo, Y.-W. 2013. Bioactive polyhydroxylated steroids from the Hainan soft coral Sinularia depressa Tixier-Durivault. Bioorganic \& Medicinal Chemistry Letters, 23(5), 1334-1337.
Liang, L. F., Guo, Y. W. 2013. Terpenes from the soft corals of the genus Sarcophyton: Chemistry and biological activities. Chemistry and Biodiversity, 10(12), 21612196.

Madigan, M., Martinko, J., Parker, J. 2000. Brock Biology of Microorganisms (9th ed.). New Jersey: Prentice-Hall Inc.

Putra, M. Y., Wibowo, J. T., Murniasih, T., Rasyid, A. 2016. Evaluation of antibacterial activity from Indonesian marine soft coral Sinularia sp. AIP Conference Proceedings, 1744.

Rachmaniar, R. 1995. Penelitian Produk Alam Laut Skreening Substansi Bioaktif. Laporan. Jakarta.

Radić, N., Strukelj, B. 2012. Endophytic fungi: the treasure chest of antibacterial substances. Phytomedicine: International Journal of Phytotherapy and Phytopharmacology, 19(14), 1270-1284.

Rahal, J. J., Simberkoff, M. S. 1979. Bactericidal and bacteriostatic action of chloramphenicol against meningeal pathogens. Antimicrobial Agents and Chemotherapy, 16(1), 13-18.

Rajaram, S., Ramesh, D., Ramulu, U., Anjum, M., Kumar, P., Murthy, U.S.N., Venkateswarlu, Y. 2014. Chemical examination of the soft coral Sinularia kavarattiensis and evaluation of antimicrobial activity. Indian Journal of Chemistry - Section B Organic and Medicinal Chemistry, 53(8), 1086-1090.

Rice, L. B. 2008. Federal funding for the study of antimicrobial resistance in nosocomial pathogens: no ESKAPE. The Journal of Infectious Diseases, 197(8), 1079-1081.

Rina. 2011. Substansi Antibakteri dari Ascidian dan Jamur Laut yang Berasosiasi Dengannya. Thesis. Sam Ratulangi University.

Rozirwan, Bengen, D. G., Zamani, N. P., Effendi, H., Chaidir. 2014. Screening on the potential bioactive compounds of antibacterial activity in soft coral collected from South Bangka Island Waters and Lampung Bay. Jurnal IImu Dan Teknologi Kelautan Tropis, 6(2), 1-38.

Sarma, N. S., Krishna, M. S., Pasha, S. G., Rao, 
T.S.P.,Venkateswarlu, Y., Parameswaran, P. S. 2009. Marine metabolites: The sterols of soft coral. Chemical Reviews, 109(6), 2803-2828.

Shaaban, M., Shaaban, K. A., Ghani, M. A. 2013. Hurgadacin: a new steroid from Sinularia polydactyla. Steroids, 78(9), 866-873.

Sun, P., Meng, L. Y., Tang, H., Liu, B. S., Li, L., Yi, Y., Zhang, W. 2012. Sinularosides A and $B$, bioactive 9,11-secosteroidal glycosides from the South China Sea soft coral Sinularia humilis Ofwegen. Journal of Natural Products, 75(Table 1), 16561659.

Tanod, W. A., Mangindaan, R. E., Kapojos, M. 2015. Aktivitas Antimitotik Dari Ekstrak Karang Lunak Genus Sinularia. OmniAkuatika, 11(2), 41-49.

Wang, S.-K., Hsieh, M.K., Duh, C.-Y. 2013. New diterpenoids from soft coral Sarcophyton ehrenbergi. Marine Drugs, 11(11), 43184327.

Wright, G. D., Sutherland, A. D. 2007. New strategies for combating multidrug-resistant bacteria. Trends in Molecular Medicine, 13(6), 260-267.

Zhao, M., Yin, J., Jiang, W., Ma, M., Lei, X., Xiang, Z.,Yan, P. 2013. Cytotoxic and antibacterial cembranoids from a South China Sea soft coral, Lobophytum sp. Marine Drugs, 11(4), 1162-1172. 